Stanisław WÓJCIK

Katolicki Uniwersytet Lubelski

\title{
Kierunki przekształceń świadomości narodowej Polaków w przededniu wejścia do Unii Europejskiej - pytania badawcze
}

\section{W} ciąż trudno jest podać taką definicję narodu, która zadowoliłaby większość znawców tej problematyki. Naturę narodu kształtuje bowiem bardzo wiele czynników. Sądzę jednak, że można się zgodzić, że naród ma dwa podstawowe składniki: przedmiotowy i podmiotowy. Składnik przedmiotowy to wspólne pochodzenie (w punkcie wyjściowym), wspólna historia, tradycja i koleje losu, wspólnota codziennej egzystencji, wspólna ojczyzna jako środowisko macierzyste, wspólna ,czasoprzestrzeń” oraz wspólna organizacja życia i technika („natura narodu”); składnik podmiotowy to wspólna świadomość i samoświadomość, poczucie narodowe, samowładność, kultura duchowa, język (w szerokim znaczeniu), kodeks wartości i idei, przyswojona i przeżywana religia, wspólnota uczuć i prakseologii, poczucie jednego theatrum gentis, a w rezultacie rodzaj wspólnej podmiotowości, „osobowość” narodu. Zgodnie z tym poczuciem naród określamy jako naturalną, trwałą społeczność ludzi, przede wszystkim rodzin, zespoloną witalnie i psychicznie, na bazie wspólnoty pochodzenia i ojczyzny w punkcie wyjścia, związaną ściśle w czasoprzestrzenną wspólnotę i w żywy organizm biologiczno-społeczny (szczególnie dzięki tej samej tradycji, historii, kulturze, aksjologii, także religii), samorealizujący się w postaci określonego podmiotu o charakterze zbiorowej osobowości ${ }^{1}$. Naród nie jest więc fikcją, mitem czy abstrakcją, ale konkretnym zbiorem ludzi, tworzących razem typ wspólnej osoby.

Od początku XIX wieku w europejskiej myśli politycznej obserwujemy zarówno awans pojęcia naród - w romantyzmie, idealizmie niemieckim, w polskich ruchach wyzwoleńczych, jak i falowe ataki, zmierzające

1 Cz. S. Bartnik, Fenomen Europy, Lublin 1998, s. 202-203. Por. S. Kowalczyk, Naród, państwo, Europa, Radom 2003, s. 13-26. 
do jego wyeliminowania przez socjalizm, marksizm, pozytywizm, liberalizm czy strukturalizmy. Również obecnie, jak się wydaje, stanowisko antynarodowe dominuje. Słowo naród jest wypierane zarówno z polityki, jak i z nauk - historii, socjologii, a nawet $\mathrm{z}$ literatury. Ta tendencja do odrzucenia terminu naród ma swoje przyczyny, a mianowicie skrajny indywidualizm, ideę autokracji oraz ateizm społeczny. Los słowa naród dzielą także pojęcia pochodne: ojczyzna, patriotyzm, honor. Tak więc dla jednych, dla agresywnej mniejszości, naród jest mitem, a dla drugich - nie tylko dziedzictwem, lecz i dzisiaj wielokształtnie zespoloną społecznością ludzi, a przede wszystkim rodzin. W wydanej przed kilku miesiącami publikacji pisałem: „Co szczególnie może niepokoić dzisiaj, to urabianie niedobrej atmosfery wokół problematyki narodu. Oto dawni komuniści, a obecnie neokomuniści, liberałowie widzą się teraz w roli inżynierów społecznych, którzy chcą mieć pełną swobodę w kształtowaniu nowoczesnej społeczności. Najczęściej jednak popadają w patos, pisząc o swych dążeniach do kształtowania nowego społeczeństwa obywatelskiego i państwa prawa [...]. Nie poczuwają się jednak do odpowiedzialności za modelowanie, w gruncie rzeczy utopijnych, wizji bytu zbiorowego [...]. Sowieci nie chcą odpowiadać za to, że ze społeczeństwa zrobili łagier, a biznesmeni i liberałowie uważają, że mają prawo czynić ze społeczeństwa nędzarzy i niewolników [...]. Uważam [...], że z narodem nie da się tego przeprowadzić tak bez skrupułów, bo naród jest rzeczywistością osobową. Tymczasem obserwuje się nagminnie, jak wielu tych neofitów liberalizmu, zliberalizowanych komunistów, postmodernistów poniewiera patriotyzmem, podważa tradycje narodowe, atakuje wartości chrześcijańskie",2. Moim zdaniem należy czynić wszystko, aby te przeciwieństwa niwelować z obu stron.

W tym miejscu należy przypomnieć, że uwagi teoretyczne dotyczące interpretacji fenomenu narodu sięgają aż do starożytności, nie tylko żydowskiej i greckiej. Pojęcie narodu było znane we wszystkich wielkich cywilizacjach pierwotnych, np. w Sumerze, w Egipcie czy w Chinach ${ }^{3}$. Ludy te miały wyraźnie wykształconą świadomość swej odrębności od innych zbiorowości tzw. pogan, barbarzyńców. Miały też poczucie własnego powołania, oddania wspólnocie, w której żyły.

2 S. Wójcik, Naród polski w publicystyce PRL, Lublin 2002, s. 9.

3 M. A. Krapiec, Wprowadzenie do filozofii polityki, Lublin 1992, s. 53; Cz. S. Bartnik, Historiologia w kulturach starożytnych, Lublin 2000; S. Wójcik, Naród i państwo w myśli społecznej II Rzeczypospolitej, Lublin 1987, s. 31, 72. 
W okresie renesansu zaczęła się odradzać wiara w dawne wartości, w tym i narodowe. Zaczęto rozczytywać się w tekstach politycznych starożytności i wydobyto z nich myśli o miłości ojczyzny, o poświęceniu się dla polis, przypomniane m.in. przez Niccola Machiavellego.

Kolejny etap w kształtowaniu się poczucia narodowego wyznaczyły rewolucje: angielska z XVII wieku, łącząc świadomość narodową Anglików z poczuciem wolności obywatelskiej, amerykańska rewolucja niepodległościowa, która wyartykułowała problem praw człowieka-obywatela, a także uchwalona w 1789 roku przez rewolucjonistów francuskich Deklaracja Praw Człowieka i Obywatela. Zapisano w niej, że źródłem wszelkiej władzy jest naród.

Główną zdobyczą światowej myśli politycznej było więc stworzenie koncepcji narodu jako wspólnoty obywatelskiej, państwowo-politycznej. Zasadniczym łącznikiem w tej koncepcji nie jest język i historia, lecz prawa i poczucie obywatelskie. Ten typ pojmowania narodu dominuje do dzisiaj w myśli politycznej Zachodu.

Nieco inne, szersze rozumienie problematyki narodowej ukształtowało się w Europie Środkowowschodniej, a mianowicie pojęcie narodu oparto tu na wartościach kultury etnicznej. Jednym z pierwszych badaczy tego zagadnienia był Johann G. Herder. Był on przekonany, że wspólnoty narodowe mają lepszą przyszłość, jeśli wypowiadają swoje podstawowe wartości w języku ojczystym, przez własne tradycje i obyczaje.

Wraz z ukształtowaniem się takiego kulturowego ujęcia narodu od drugiej połowy XIX wieku obserwować można rozwój nacjonalizmu i kosmopolityzmu. Jak wiadomo, nacjonalizm zrodził się w państwach niemieckich w okresie wojen napoleońskich. Poniżone poczucie narodowe wyrażali Johann G. Fichte, Ernst M. Arndt, Friedrich Jahn. Także na ziemiach polskich obok patriotyzmu rozwinął się nacjonalizm jako forma obrony wobec agresywnych nacjonalizmów Prus i Rosji. Ten typ nacjonalizmów do dzisiaj można spotkać w tej części Europy.

Należy też odnotować próby współpracy pomiędzy narodami. Nie sięgając w odległą przeszłość, trzeba stwierdzić, że posunięcia takie występowały już w latach trzydziestych XIX wieku za sprawą Giuseppe Mazziniego. Starał się on przeciwstawić pokojowo nastawione narody despotycznym władzom. Podobny zamysł mieli rewolucjoniści Wiosny Ludów, akcentujący braterstwo ludów. Dalsze próby dokonywały się dzięki ruchom międzynarodowym, takim jak: pangermanizm, panslawizm, pan- 
azjatyzm, faszintern, komintern, tj. międzynarodową solidarność ruchów i rządów faszystowskich czy komunistycznych ${ }^{4}$.

Dzisiaj obserwujemy bardzo zaawansowaną próbę jednoczenia państw europejskich w ramach Unii Europejskiej, co sprawia, że odżywają dyskusje na temat zasadniczych przeobrażeń świadomości narodowej, jakie zapewne dokonują się szczególnie wśród narodów państw kandydackich.

Już na początku tego procesu, podczas kongresu intelektualistów europejskich w Hanowerze (październik 1991), pojawiły się głosy mówiące otwarcie, że państwa członkowskie UE powinny rezygnować ze swej suwerenności. W miejsce narodu miałaby powstać społeczność ponadnarodowa. Jak można sądzić, niektórzy uczestnicy mylili państwo z narodem. Niewątpliwie Unia może domagać się od państwa rezygnacji z niektórych jego suwerennych praw, może nawet żądać od niego zrezygnowania z odrębnej armii, zniesienia granic czy emisji własnej waluty, ale mimo wszystko państwa nie utracą zupełnie suwerenności. Jak trafnie zauważa S. Jedynak, gdyby nawet tak się stało, nie oznaczałoby to, że dojdzie do zespolenia się narodów w jedną całość. Jakim mówiono by językiem? Nieprawdą jest też, że naród jako jednostka podziału stracił już na znaczeniu. W Europie zauważamy coś odmiennego. Rozwijają się narody, rośnie patriotyzm, a także nacjonalizm. Wystarczy obserwować choćby emancypację narodową Słowaków, Litwinów, Słoweńcow, Katalończyków czy Walonów. Nie słabnie też poczucie narodowe Niemców ${ }^{5}$.

W stosunku do dostrzeganych wciąż grup etnicznych wskazywano, że nowa Europa musi podporządkować sobie element etniczny i przekształcić go w europejską świadomość wspólnoty. Proces ten powinien się dokonać tak, aby grupy wyrażały swą wolę wolnego wyboru. Jak mówił J. Rovan, idea jednego narodu europejskiego powinna stać się w sposób konieczny źródłem wspólnego poczucia wartości ${ }^{6}$.

Te głosy dzisiaj są wyciszane. Ale rodzi się pytanie, czy program budowy takiej ,imperialnej” UE może być atrakcyjny dla nowych członków. Występują dwie wyraźnie sprzeczne tendencje, które jednakże dadzą się pogodzić - budować ponadnarodowe wspólnoty gospodarcze i polityczne z poszanowaniem tożsamości wszystkich narodów, a więc godności własnej oraz odrębności kulturowej i obyczajowej.

4 S. Jedynak, Naród, społeczeństwo, państwo. Studia z filozofii społecznej XIX i XX wieku, Warszawa 2002, s. 62.

5 Ibidem, s. 64.

6 Za P. Koslovski, Europa jutra, Lublin 1994, s. 66 i n. 
Podzielam ostateczną konkluzję S. Jedynaka, że potrzebne są wspólnoty międzynarodowe i że godna poparcia jest tendencja do utworzenia wspólnoty europejskiej, tak samo jak w przyszłości powinna się wytworzyć wspólnota afrykańska, bliskowschodnia, wschodnio-azjatycka. Jednakże koncepcja utrzymująca, iż w ślad za taką wspólnotą ,państwową" ukształtuje się jeden naród, jest naiwna. Świat powinien być różnorodny, tak jak różny jest człowiek ${ }^{7}$. Warto tutaj przypomnieć naszą zasadę unijną, realizowaną przez I Rzeczpospolitą w XVI wieku z narodami sąsiednimi: wolni z wolnymi, równi $\mathrm{z}$ równymi.

Dzisiejsza nowa integracja europejska nie powinna być budowana potajemnie i powinna być równoprawna. Jak na razie, proces poszerzania UE przypomina aż za bardzo ideę pannacjonalistyczną. Ten właściwy kierunek to budowa wspólnoty narodów Europy, której zasady stanowiłyby: precyzyjnie wyartykułowane demokratyczne zasady w stosunkach między narodami (podział władzy i ról, suwerenność i inne); wzajemna pomoc poprzez system bezpieczeństwa zbiorowego; stosunki szczegółowe między narodami i państwami oparte nie tylko na prawie międzynarodowym, ale i zasadach etyki; żaden kraj nie powinien być uprzywilejowany i nie może dojść do supremacji jednego czy dwóch państw w tym systemie.

Jaką samoświadomość, jakie doświadczenia, osiągnięcia, problemy i argumenty może wnieść Polska dla takiej wspólnotowej orientacji Europy? Ustrój państwa polskiego, jaki z wielkimi oporami powstawał w ciagu czternastu lat transformacji systemowej, jest obecnie określany przez część politologów i socjologów jako ograniczona czy wręcz fasadowa demokracja polityczna (państwo partyjne) i niekonsekwentnie działający mechanizm rynkowy. Jak zauważa E. Mokrzycki mechanizm demokratyczny działa w Polsce poprawnie, ale tylko na ograniczonym obszarze życia politycznego, obejmuje mianowicie zasadniczo społeczeństwo, ale - jak na razie - słabo wkracza w sferę rzeczywistych relacji politycznych, które utrzymują się od czasów schyłku władzy komunistycznej, czyli wyłącza tzw. władzę i bojowe środowiska pracownicze, ich polityczną reprezentację ${ }^{8}$. Mamy więc młodą, nierozwiniętą demokrację i stary układ sił politycznych.

S. Jedynak, Naród..., op. cit., s. 65.

${ }^{8}$ E. Mokrzycki, Oswajanie rynku i demokracji, maszynopis referatu wygłoszonego na XI Ogólnopolskim Zjeździe Socjologicznym, Rzeszów 2000, s. 2; J. Staniszkis, Postkomunizm: próba opisu, w: K. W. Frieske, W. Morawski, W biegu czy w zawieszeniu? Ludzie i instytucje w procesie zmian, Warszawa 1994; A. Zybertowicz, Demokracja jako fasada: przypadek III RP, maszynopis referatu wygłoszonego na XI Ogólnopolskim Zjeździe Socjologicznym, Rzeszów 2000. 
Pewnym optymizmem napawa sytuacja w kontekście efektów reformy administracji państwa, chociaż i tu łatwo dostrzec liczne zagrożenia. Ale nie można zapomnieć, że ta wielka reforma państwa wynikała z potrzeby dostosowania Polski do wymaganych standardów unijnych.

Co nas dzisiaj szczególnie niepokoi w odniesieniu do sytuacji i klimatu duchowego panującego w UE, jak i w Polsce? Wiadomo, że po Maastricht II (1997) UE stała się na swych szczytach władzy i ideowych masońska, i chce się poszerzyć na nowe kraje nie na prawach partnerskich, lecz kolonialnych. Czy europejska biurokracja nie ma na uwadze jedynie obrony kluczowych interesów najsilniejszych państw UE? Dlaczego na przykład nie pozwala się Polakom uregulować prawnie ich tytułu do ziem zachodnich i północnych oraz całej kwestii uwłaszczeniowej? Polscy politycy i decydenci sprawiają wrażenie, że nie mają żadnej wizji Polski. Nie wiedzą, co to jest Polska, jakim kierują narodem, jaka jest nasza racja stanu. Można jedynie powiedzieć, że ich obraz państwa jest raczej marksistowski. Świadomość narodowa, naród to dla nich mity. Nie można też pominać pewnego fałszu społeczno-gospodarczego. Nasz kraj od roku 1989 jest pod tak dużym naciskiem ośrodków politycznych i finansowych Zachodu, że polscy decydenci jakby nie mogą przeszkadzać w kolonizowaniu kraju, niszczeniu przemysłu, świata robotniczego i wiejskiego. Wreszcie nie można nie dostrzegać niekompetencji rządzących. Polacy oczekują, kiedy ustaną rządy dyletantów. Tymczasem wciąż zarówno na wysokich stanowiskach, jak i w terenie ludzie są w większości indolentni, bez zmysłu społecznego, często aroganccy, budujący wszystko na kłamstwie i chytrości. Propagandę prounijną w Polsce cechuje ogólnikowość, jakkolwiek można się domyślać, że realne warunki ekonomiczne i prawne zapowiadają się niekorzystnie dla nas, jako typowo satelickie. Dominują hasła, takie jak: jedność, demokracja, poszanowanie pluralizmu, dobrobyt itp. Czy nie jest to przypadkiem obliczone na niski poziom umysłowy Polaków? Chyba tak, bo trudno nie odnotować dość silnego u części młodych Polaków ślepego pędu do UE. Przemilcza się też w propagandzie podstawowe fakty. Daje się zauważyć, że od 1997 roku chrześcijańskie kształtowanie Unii zostało zarzucone. Unia nie przyznaje Kościołowi katolickiemu żadnych praw, chce jedynie uznać status prawny Kościoła w każdym kraju z osobna. Nadto odnosi się wrażenie, że jesteśmy uważani za coś w rodzaju „trzeciej Europy”.

Dla myślących Polaków sytuacja ta skłania do postawienia kolejnych zasadniczych pytań. Czy przy tylu niejasnościach nie powinno się odłożyć podpisania traktatu akcesyjnego? A w związku z tym, czy nie będzie nam 
grozić izolacja? Czy naprawdę nie jest możliwa współpraca w sposób wolny z całym światem? Czy UE nie powinna się wpierw zreformować w sposób godny i ludzki? A może polskość i europejskość w ogóle się wykluczają? Takie pytania są dzisiaj często stawiane, a odpowiedzi na nie padają różne. Moim zdaniem oba te światy wzajemnie się warunkują, ale z akcentem na zachowanie tożsamości narodu, kultury, języka, ojczyzny, religijności. Podzielam pogląd Cz. S. Bartnika, że tożsamość Polski jest drogą Europy, a prawdziwa Europa jest drogą jej narodów ${ }^{9}$. Jednocześnie chciałbym podkreślić, iż nie jest z tym sprzeczny postulat poprawy poziomu i sposobu życia Polaków.

Trudno też nie postawić innego problemu, a mianowicie, jaki charakter powinna mieć władza nowej Europy: monocentryczny czy policentryczny. Wszyscy podkreślają znaczenie policentryzmu jako zasady przy podejmowaniu decyzji, ale gdy pojawiają się trudne i skomplikowane sytuacje, zasadnicze dla świata i Europy, to tzw. wielcy narzucają decyzje słabszym, czego przykładem był ostatnio przypadek skarcenia polityków polskich za samodzielność w podejmowaniu decyzji w polityce zagranicznej przez prezydenta Francji.

Dla Europejczyków-chrześcijan ważne też będzie zdefiniowanie, co to jest dobro wspólne Europy. Zdaniem Cz. S. Bartnika pojęcie to może zostać zdefiniowane dopiero wtedy, kiedy określi się samą Europę. Europa staje się więc problemem, wyzwaniem społecznym, zadaniem. Trzeba powiedzieć wyraźnie, czy chodzi nam o Europę gospodarek, państw, narodów, religii, czy raczej po prostu o Europę ludzi. Czy będzie to byt realny, czy też abstrakcja, jakaś techniczna idea. W efekcie rozumienie dobra wspólnego Europy będzie zależeć od jej ogólnej wizji. Dobrem najwyższym i najbardziej wspólnym według tego autora jest człowiek, jego istota, istnienie, życie, wszechstronny rozwój. Człowiek nie może być jednak rozumiany jedynie jako niezależna jednostka, do czego dąży się często na Zachodzie, ale zarazem także jako zbiorowość narodowa i docelowo jako „Europa Osób”. Czynnik ludzki, który jest sensem Europy, musi się ściśle łączyć z czynnikiem materialnym, stanowiącym konieczne środowisko egzystencji, historii i twórczości Hominis Europaei ${ }^{10}$.

Uważa się dzisiaj, że narody, państwa, kultury, religie godzą się na jedną Europę. Zgoda taka, oczywista w gospodarce, technice, naukach,

9 Cz. S. Bartnik, Fenomen..., op. cit., s. 251.

10 Ibidem, s. 264. 
jest znacznie trudniejsza w ideach i religii. Czy więc nie należy zacząć myśleć o wypracowaniu Wielkiej Karty Praw i Obowiązków Nowej Europy? Do tego potrzebna będzie wiedza, w jakiej Europie będziemy się dobrze czuć. Podzielam przekonanie oparte na naszych polskich doświadczeniach, że najlepsza wydaje się koncepcja Europy Narodów. Mogłaby ona tworzyć Rodzinę Narodów, bez granic politycznych i gospodarczych, żyjąca w równości praw i obowiązków. Ateiści oskarżają taką wizję o nacjonalizm, bo nie chcą przyznać człowiekowi wartości absolutnej. Oni chcieliby żeby o kształcie życia indywidualnego i zbiorowego decydowali tylko przywódcy polityczni, finansiści, cynicy. Europę jako „ruch obywatelski” lub „wielką spółkę z o.o.” chcą traktować jako swoje przedsiębiorstwo. W tej sytuacji należy dostrzegać możliwość popełnienia trzech błędów: 1) rozbicia na luźne elementy, nie stanowiące całości europejskiej; 2) zniwelowania wielości, a stworzenia jedności sztucznej, technicznej; 3) hegemonii jednego ośrodka, najsilniejszego jednego państwa, jednej kultury czy jednej doktryny społecznej (np. socjaldemokracji) ${ }^{11}$. Uważam, że najbardziej realistyczne jest takie rozwiązanie, gdzie będzie jedność w różnorodności i różnorodność w jedności.

Na koniec warto poddać pod rozwagę kwestię zakłamania. Dzisiaj wyraźnie widzimy, jak na przestrzeni dziejów, a zwłaszcza współcześnie, wielką karierę polityczną robi oszustwo, które przekształca się niemalże w cywilizację zakłamania. Zakłamanie ciągle się doskonali technicznie pisze Bartnik - tak, że coraz trudniej odróżnić je w życiu publicznym od prawdy. Coraz częściej nie potrafi tego uczynić zwykły człowiek. Jak rozwija się cywilizacja zakłamania, wiedzą lepiej niektórzy politycy oraz sternicy mass mediów. Mają tutaj miejsce niezliczone manipulacje. Prawdę podaje się jako fałsz, fałsz jako prawdę, wiedzę pozorną jako prawdziwą, niepewną jako pewną itd. Wszystko to robi się najczęściej dla celów politycznych i ekonomicznych. Współczesna cywilizacja zaczyna tak funkcjonować, że nie sposób zarobić na prawdzie, natomiast na kłamstwie zarabia się ogromne pieniądze. Kłamstwo i oszustwo stają się kategorią kultową i sposobem życia. Nie da się ich szybko i łatwo wyplenić. Co więc należy czynić, zwłaszcza w Polsce? Wierząc, że ostatecznie tylko prawda zwycięża, trzeba tworzyć cywilizację prawdy, opartą na Ewangelii, cywilizację katolicyzmu. Należy rozwijać od dziecka apostolstwo prawdy, zwykłej prawdy, kultury każdej prawdy. Musi też ożyć na nowo

11 Ibidem, s. 278. 
nasz krytycyzm w stosunku do tych mass mediów, które nie chcą służyć prawdzie. Trzeba, żeby kłamstwo było społecznie traktowane jako zło, nie zaś jako rzekoma nowoczesność czy nieunikniona konieczność życia ${ }^{12}$. Obecny stan kultury i cywilizacji zachodniej jest wyrazem dynamicznego postępu technicznego, który dokonuje się kosztem kultury duchowej. Postęp jest zwrócony wyłącznie na wartości materialne. Taką sytuację odrywania się cywilizacji od swej podstawy duchowej rejestrowano już wcześniej. Przywracanie równowagi rozwiązywano na dwa sposoby, które warto przypomnieć: poprzez powrót do chrześcijańskich korzeni oraz kształtowanie osobowości człowieka. Pomagało to społeczeństwom wyrwać się z demoralizacji i degradacji socjalnej, rozwijało nowe treści humanizacji.

Europa Zachodnia jest w zasadzie ukształtowana. Wytworzyła sprawne mechanizmy funkcjonowania w takich dziedzinach, jak polityka, gospodarka, technika, nauka, cywilizacja, prawo, zdrowie czy kultura. Dla nas z Europy Centralnej i Wschodniej jest czymś w rodzaju raju europejskiego. Trudności jawią się dopiero w dziedzinie światopoglądowej i religijnej, jakkolwiek Zachód nie zdaje sobie z tego sprawy albo te sfery bagatelizuje. Czy państwa kandydujące sprostają kryteriom stawianym przez UE? Mamy do rozstrzygnięcia następujące kwestie:

1) Czy wstępując do UE dla spodziewanych korzyści ekonomicznych i technicznych, nie będzie trzeba z czasem zrezygnować z uznawanych przez nas systemów wartości klasycznej kultury zachodniej i chrześcijańskiej? Nie jesteśmy przygotowani do innej moralności niż dekalogiczna, a może być ona zwalczana przez prawodawstwo zachodnie (legalizacja aborcji, eutanazji, małżeństw homoseksualnych itp.);

2) Co z bezpieczeństwem i suwerennością państwa? W UE dotychczas nie jest skrystalizowana idea państwa. $Z$ jednej strony neomarksizm, socjaldemokracja i liberalizm są przeciwko silnemu państwu, a z drugiej zaś jakaś inżynieria europejska chce stworzyć z całej Europy jedno wielkie państwo. W tej sytuacji my nie rozumiemy polityki Zachodu. Wydaje się ona sprzeczna wewnętrznie. Poza tym nie chcemy zlikwidować własnego państwa, o które walczyliśmy przez ostatnie trzysta lat;

3) Czy powinniśmy się spieszyć z wejściem do UE, zważywszy na ruinę naszej gospodarki, głębokie rozbicie polityczne w Polsce, brak repre-

12 Ibidem, s. 281, 283-284. 
zentacji w rządach większościowego społeczeństwa polskiego. Czy nie powinniśmy wpierw zdobyć pełną suwerenność w państwie, odbudować gospodarkę, życie społeczne, kulturalne, uwiarygodnić nasze władze, poznać wszystkie tajne elementy układu akcesyjnego i dopiero wtedy, za 10-20 lat, nie zrywając przez ten czas współpracy z UE, wynegocjować pełną integrację. Obecne parcie ku UE jest dość brutalne, zaciemnione, bez zaufania do negocjatorów z obu stron. Mamy wrażenie, że gna się nas do jakiegoś nowego kołchozu, gdzie nie będziemy o niczym decydowali, że nie odbudujemy gospodarki. Dotychczas udzielane nam pożyczki były sposobem niszczenia naszej gospodarki i inwencji;

4) Zmienia się obecnie nastawienie społeczeństwa polskiego wobec akcesji do UE. Zwątpienie w jej sens szerzy się szczególnie na prowincji, która jest najbardziej dotknięta złymi skutkami gospodarki krajowej i zachodniej ${ }^{13}$. W pierwotnych intencjach i wyjściowej doktrynie UE integracja miała być dla nas bardzo korzystna, dlatego początkowo społeczeństwo wysoko ją popierało. Po 12 latach współpracy zwątpiliśmy w szczerość UE, doznaliśmy wielu krzywd gospodarczych i ideowych. Zostały opanowane nasze media, zabrano banki, rozbito przemysł, zniszczono wieś i rzemiosło. Wpędzono nas w olbrzymie bezrobocie, które wypływa niewątpliwie ze zniszczenia zakładów przez malwersantów swoich i obcych oraz z neokapitalistycznej doktryny niektórych zachodnich ideologów, o czym również świadczy rosnące bezrobocie w krajach zachodnich, np. w Niemczech i we Francji. W tej sytuacji tylko niewyrobiona politycznie młodzież nie widzi trudności, popiera integrację, mając nadzieję, że wyrwie się z nędzy i ucisku w Polsce, ale jest to kompletne złudzenie. Młodzież liczy, że będzie się kształciła za pieniądze Zachodu. Poza tym do UE prą politycy i część urzędników, chcąc uniknąć odpowiedzialności przed narodem za swoją antynarodową działalność;

5) Należy wyjaśnić naukowo, dlaczego społeczeństwa Zachodu, zwłaszcza państw mniejszych (np. Austrii), coraz głośniej skarżą się na warunki panujące w UE i wręcz żałują, że do niej wstąpiły;

6) Forsowanie obecnie przez ideologów francuskich, niemieckich i włoskich tworzenia z Europy jednego państwa ponadnarodowego zaprze-

13 Polska lokalna wobec integracji europejskiej, pod red. Z. Macha i D. Niedźwiedzkiego, w: Universitas, katalog Wiosna 2003, s. 24. 
cza absolutnie naszej polskiej świadomości narodowej, w tym także katolickiej, kulturowej, językowej, bo nie sposób stworzyć sztucznie i w tak krótkim czasie nowego narodu europejskiego. Realnie biorąc, może się on ukształtować po paru tysiącach lat. Populus Romanus, czyli naród rzymski, nie stał się - mimo ponadtysiącletniej historii jednym narodem, lecz rozpadł się w V wieku na wiele narodów, czyli na swoje części składowe. Gwałtowne montowanie narodów w jeden naród tchnie rosyjskim bolszewizmem.

\section{Summary}

The shape of Western Europe is settled in principle. For us - the people of Central and Eastern Europe - it is something of a European paradise. The difficulties emerge only in the realm of the philosophy of life and religion, although the West either does not realize these problems or neglects them. Can the candidate states meet the criteria the European Union has established? The following dilemmas should be solved here: as we access the EU in order to obtain forecasted economic and technical benefits, may we have to abandon with time our systems of values that are classical for European and Christian culture? What about the State security and sovereignty? Should we hasten to access the EU given the ruined economy, profound political divisions in Poland and the absence of the majority representation of the Polish society in the government? The attitude of Polish society to the accession to the EU is currently undergoing a transformation. The doubts about its value spread particularly in the provinces where the adverse results of wrong domestic and western economy are most acute. It should be scientifically explained why Western societies, in particular those of smaller states, such as Austria, increasingly complain about the conditions in the EU and actually regret their own accession. French, German and Italian ideologists propagate the creation of a single supranational state out of the whole Europe. This stands in direct opposition to the Polish national consciousness, including the Catholic, cultural and linguistic consciousness, as it is impossible to artificially create a new European nation in such a short time. 